\title{
Phototherapy for hyperbilirubinaemia in very low birthweight infants
}

\author{
MARTIN W. MONCRIEFF and JANET DUNN \\ From the Special Care Baby Unit, City Hospital, Derby
}

\begin{abstract}
Moncrieff, M. W., and Dunn, J. (1976). Archives of Disease in Childhood, 51, 124. Phototherapy for hyperbilirubinaemia in very low birthweight infants. Phototherapy was used to treat 20 newborn babies whose birthweight was below $1500 \mathrm{~g}$ and whose plasma bilirubin exceeded $8 \mathrm{mg} / 100 \mathrm{ml}$. The plasma bilirubin level was maintained below $13 \mathrm{mg} / 100 \mathrm{ml}$ except in 4 babies whose level exceeded $13 \mathrm{mg} / 100 \mathrm{ml}$ before treatment was started. In $60 \%$ of an untreated group of larger babies previously reported the plasma bilirubin level exceeded this figure.

Phototherapy seems to control the plasma bilirubin level satisfactorily in very low birthweight infants, but frequent measurements on the second and third days of life are advised in order that treatment may be started promptly when it exceeds $8 \mathrm{mg}$ / $100 \mathrm{ml}$.
\end{abstract}

Phototherapy controls hyperbilirubinaemia in low birthweight infants when used prophylactically (Lucey, Ferreiro, and Hewitt 1968) or selectively for babies whose plasma bilirubin level exceeds $10 \mathrm{mg} / 100 \mathrm{ml}$ (Elliott, Moncrieff, and George 1974). The less mature the baby, however, the more rapidly the plasma bilirubin rises, and for this reason it seemed unethical to include babies weighing less than $1500 \mathrm{~g}$ at birth in our previous controlled study (Elliott et al., 1974). Few babies under $1500 \mathrm{~g}$ birthweight are included in other series, and we have not found a report devoted exclusively to phototherapy in these infants. We have therefore undertaken a study without a control group to see if phototherapy would control hyperbilirubinaemia in very low birthweight babies. We report our results in this paper.

\section{Patients and methods}

During the two years March 1973 to February 1975 42 babies weighing between $1000 \mathrm{~g}$ and $1499 \mathrm{~g}$ at birth were admitted to the Special Care Baby Unit in Derby (this was moved in March 1973 to new, well-lit, purposebuilt accommodation). The total plasma bilirubin concentration in those babies who developed clinical jaundice was measured daily, or more often if indicated, by means of the AO reflectance meter. Babies whose plasma bilirubin exceeded $8 \mathrm{mg} / 100 \mathrm{ml}$ were treated with continuous phototherapy until the

Received 15 May 1975. level had fallen to below $8 \mathrm{mg} / 100 \mathrm{ml}$. Details of treatment, nursing care of the babies, and the precautions observed were the same as already described (Elliott et al., 1974). 17 of the babies died within 48 hours of birth and did not develop significant jaundice. In 20 of the remaining 25 babies the serum bilirubin concentration exceeded $8 \mathrm{mg} / 100 \mathrm{ml}$, and clinical details of these babies together with those of untreated, larger babies from our previous study are shown in Table I. One baby in this series received phenobarbitone, but no baby was given any drug known to potentiate jaundice and none had known blood group incompatibility. There was no untreated control group in the study.

\section{TABLE I}

Clinical details of 20 very low birthweight babies and of untreated, larger babies from previous study

\begin{tabular}{l|l|l}
\hline & $\begin{array}{c}\text { Very low } \\
\text { birthweight } \\
(\mathrm{n}=20)\end{array}$ & $\begin{array}{c}\text { Untreated, } \\
\text { larger babies } \\
(\mathrm{n}=45)\end{array}$ \\
\hline $\begin{array}{l}\text { Sex }(\mathrm{M} / \mathrm{F}) \\
\text { Birthweight (g) } \\
\text { mean } \\
\text { range }\end{array}$ & $14 / 6$ & $27 / 18$ \\
$\begin{array}{l}\text { Gestation (w) } \\
\text { mean } \\
\text { range }\end{array}$ & 1390 & 2040 \\
$\begin{array}{l}\text { Severe asphyxia } \\
\text { neonatorum }\end{array}$ & $1170-1480$ & \\
$\begin{array}{c}\text { Respiratory distress } \\
\text { syndrome }\end{array}$ & $28 \cdot 5$ & $35 \cdot 1$ \\
\begin{tabular}{l} 
Severe bruising \\
\hline
\end{tabular} & 4 & - \\
\hline
\end{tabular}


Since the plasma bilirubin rose more rapidly than expected in many babies treatment was started in only 4 babies at levels between 8 and $10 \mathrm{mg} / 100 \mathrm{ml}$, and in 4 it exceeded $13 \mathrm{mg} / 100 \mathrm{ml}$.

\section{Results}

The number of babies whose serum bilirubin level exceeded $10,11,12,13,14$, and $15 \mathrm{mg} / 100 \mathrm{ml}$ is shown in Table II together with the comparable number of untreated, larger babies already reported (Elliott et al., 1974). The mean and upper limit of the serum bilirubin level in the very low birthweight infants on each day of treatment are shown in the Fig. Phototherapy was required for a mean

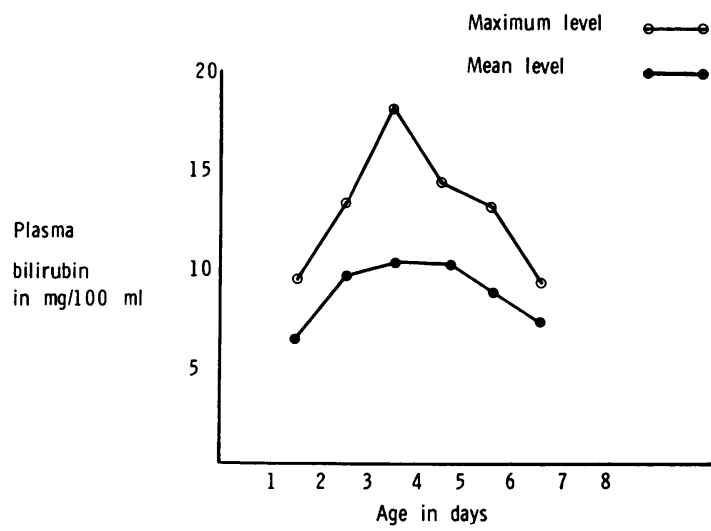

Fig.- Mean and maximum plasma bilirubin levels in very low birthweight infants treated with phototherapy.

of 48 hours with a range of 1 to 5 days. In a few cases the serum bilirubin rose after treatment was stopped and a further period of phototherapy was given. 2 babies died on the fifth and sixth days of life from hyaline membrane disease. There was no evidence of kernicterus in these 2 babies either clinically or at post-mortem examination. No side effects of treatment were observed.

\section{Discussion}

We thought it was unethical to include a control group in whom treatment was delayed, but Table II shows that in $60 \%$ of untreated, larger babies the serum bilirubin exceeded $13 \mathrm{mg} / 100 \mathrm{ml}$. Our present study shows that phototherapy will nearly always prevent the plasma bilirubin exceeding this level, even in very small infants. Of the 4 babies whose level exceeded $13 \mathrm{mg} / 100 \mathrm{ml}$ treatment was not started in 2 until the level was $14 \mathrm{mg} / 100 \mathrm{ml}$; the previous day it had been under $8 \mathrm{mg} / 100 \mathrm{ml}$ in each case. In one baby the plasma bilirubin

\section{TABLE II}

Percentage of present series of very low birthweight babies whose serum bilirubin exceeded level shown compared with the percentage of untreated, larger babies from previous study (numbers in brackets)

\begin{tabular}{c|c|c}
\hline $\begin{array}{c}\text { Bilirubin } \\
(\mathrm{mg} / 100 \mathrm{ml})\end{array}$ & $\begin{array}{c}\text { \% present series } \\
(\mathrm{n}=20)\end{array}$ & $\begin{array}{c}\text { \% previous serious } \\
(\mathbf{n}=43)\end{array}$ \\
\hline$>10$ & $75(15)$ & - \\
$>11$ & $55(11)$ & - \\
$>12$ & $45(9)$ & $72(31)$ \\
$>13$ & $20(4)$ & $60(26)$ \\
$>14$ & $10(2)$ & $49(22)$ \\
$>15$ & $5(1)$ & $44(19)$ \\
\hline
\end{tabular}

was $17 \mathrm{mg} / 100 \mathrm{ml}$ when treatment was started because, unfortunately, it had not been measured the preceeding day. It rose to $18 \mathrm{mg}$ but later fell to $16 \mathrm{mg} / 100 \mathrm{ml}$ on the day phototherapy was started. This baby was also given phenobarbitone.

We intended to begin phototherapy when the plasma bilirubin exceeded $8 \mathrm{mg} / 100 \mathrm{ml}$, but owing to the rapid rise in the second and third days of life it actually exceeded $10 \mathrm{mg} / 100 \mathrm{ml}$ in most cases before treatment was started. It might be safer to measure the plasma bilirubin at regular intervals as suggested by Tabb et al. (1972), twice a day on the second and third days of life, rather than rely on clinical judgement.

There is no absolutely safe level of plasma bilirubin in very small babies. Gartner et al. (1970) described 9 small infants who had evidence of kernicterus at post-mortem examination though the maximum serum bilirubin concentration was less than $13 \mathrm{mg} / 100 \mathrm{ml}$ in 7 . However, all were extremely ill with hyaline membrane disease and 7 weighed less than $1000 \mathrm{~g}$ at birth. Phototherapy failed to prevent kernicterus in 4 very small babies reported by Keenan et al. (1972), 2 of whom had a maximum serum bilirubin level of $10.5 \mathrm{mg} / 100 \mathrm{ml}$, but one of these 2 had meningitis and the other weighed only $454 \mathrm{~g}$ at birth. On the other hand, there was no evidence of kernicterus in the 2 babies in our series who died from hyaline membrane disease despite maximum plasma bilirubin levels of 14.5 and $12.5 \mathrm{mg} / 100 \mathrm{ml}$. Phototherapy has been used in Derby for the past 15 years. There has been no evidence of kernicterus in the survivors, even among those of very low birthweight.

Phototherapy by our method seems to prevent the plasma bilirubin exceeding $13 \mathrm{mg} / 100 \mathrm{ml}$ in nearly all cases, and this seems to be a safe level except for extremely ill infants. We have not met any serious short-term side effects of phototherapy, and long-term complications seem very unlikely 
(Lucey, 1971). Nevertheless, we are following up our previous series carefully with this in mind.

We thank Dr. B. S. B. Wood for advice in the preparation of this paper.

\section{REFERENCES}

Elliott E., Moncrieff, M. W., and George W. H. S. (1974). Phototherapy for hyperbilirubinaemia in low birthweight infants. Archives of Disease in Childhood, 49, 60.

Gartner, L. M., Snyder, R. N., Chabon, R. S., and Bernstein, J. (1970). Kernicterus. High incidence in premature infants with low serum bilirubin concentrations. Pediatrics, 45, 906.
Keenan, W. J., Perstein, P. H., Light, I. J., and Sutherland, J. M. (1972). Kernicterus in small sick premature infants receiving phototherapy. Pediatrics, 49, 652.

Lucey, J. F. (1974). Another view of phototherapy. Fournal of Pediatrics, 84, 145.

Lucey, J., Ferreiro, M., and Hewitt, J. (1968). Prevention of hyperbilirubinemia of prematurity by phototherapy. Pediatrics, 41, 1047.

Tabb, P. A. Inglis, J., Savage, D. C. L., and Walker, C. H. M. (1972). Controlled trial of phototherapy of limited duration in the treatment of physiological hyperbilirubinaemia in lowbirth-weight infants. Lancet, 2, 1211.

Correspondence to Dr. M. W. Moncrieff, Radcliffe Infirmary, Oxford. 